\title{
Myeloid and T Cell-Derived TNF Protects against Central Nervous System Tuberculosis
}

\section{OPEN ACCESS}

Edited by:

Shen-An Hwang,

University of Texas Medical School at Houston, USA

Reviewed by: Buka Samten,

University of Texas at Tyler, USA

Christoph Hölscher, Forschungszentrum Borstel (LG),

Germany

${ }^{*}$ Correspondence:

Muazzam Jacobs

muazzam.jacobs@uct.ac.za

tPresent address:

Ngiambudulu M. Francisco, Program of Immunology, Affiliated Children's Hospital of Sun Yat-sen University, Zhongshan School of Medicine, Institute of Tuberculosis Control, Sun Yat-Sen University,

Guangzhou, China; Nasiema Allie,

MRC Centre for Tuberculosis

Research, Division of Molecular

Biology and Human Genetics, Department of Biomedical Sciences, University of Stellenbosch, Stellenbosch, South Africa

\footnotetext{
Specialty section:

This article was submitted to Vaccines and Molecular Therapeutics, a section of the journal Frontiers in Immunology
}

Received: 29 October 2016 Accepted: 07 February 2017 Published: 23 February 2017

Citation: Hsu N-J, Francisco NM, Keeton R, Allie N, Quesniaux VFJ, Ryffel B and Jacobs M (2017) Myeloid and T

Cell-Derived TNF Protects against Central Nervous System Tuberculosis.

Front. Immunol. 8:180. doi: 10.3389/fimmu.2017.00180

\author{
Nai-Jen Hsu', Ngiambudulu M. Francisco ${ }^{1 \dagger}$, Roanne Keeton ${ }^{1}$, Nasiema Allie ${ }^{1 \dagger}$, \\ Valérie F. J. Quesniaux², Bernhard Ryffe/ ${ }^{2}$ and Muazzam Jacobs ${ }^{1,3,4 *}$
}

'Division of Immunology, Department of Pathology, Institute of Infectious Disease and Molecular Medicine, Faculty of Health Sciences, University of Cape Town, Cape Town, South Africa, ${ }^{2}$ CNRS UMR7355, Experimental and Molecular Immunology and Neurogenetics, Orleans, France, ${ }^{3}$ South African Medical Research Council, Cape Town, South Africa, ${ }^{4}$ National Health Laboratory Service, Johannesburg, South Africa

Tuberculosis of the central nervous system (CNS-TB) is a devastating complication of tuberculosis, and tumor necrosis factor (TNF) is crucial for innate immunity and controlling the infection. TNF is produced by many cell types upon activation, in particularly the myeloid and T cells during neuroinflammation. Here we used mice with TNF ablation targeted to myeloid and T cell (MT-TNF ${ }^{--}$) to assess the contribution of myeloid and $\mathrm{T}$ cell-derived TNF in immune responses during CNS-TB. These mice exhibited impaired innate immunity and high susceptibility to cerebral Mycobacterium tuberculosis infection, a similar phenotype to complete TNF-deficient mice. Further, MT-TNF ${ }^{-/-}$mice were not able to control $\mathrm{T}$ cell responses and cytokine/chemokine production. Thus, our data suggested that collective TNF production by both myeloid and T cells are required to provide overall protective immunity against CNS-TB infection.

Keywords: Mycobacterium tuberculosis, tumor necrosis factor, myeloid, T cell, CNS

\section{INTRODUCTION}

Tumor necrosis factor (TNF) is a pleiotropic cytokine involved in protective cell-mediated immunity against mycobacterial infection. In humans, primates and mice, TNF is shown to be essential for the maintenance of granuloma structures and for effective control of pulmonary mycobacterial replication (1-4). Mutation of the leukotriene A4 hydrolase locus, which controls the balance of pro- and anti-inflammatory eicosanoids, showed two distinct molecular routes to mycobacterial susceptibility converging on dysregulated levels of $\operatorname{TNF}(5,6)$.

Tuberculosis of the central nervous system (CNS-TB) is a severe form of extrapulmonary tuberculosis, generally caused by hematogenous dissemination of Mycobacterium tuberculosis ( $M$. tuberculosis) after primary lung infection $(7,8)$. Earlier animal models of CNS-TB enabled investigation of therapeutic strategies and understanding of immune regulation during CNS-TB despite the limitation in the route of pathogen entry to the CNS (9-11). In animal studies, similar cytokine profile was observed as in CNS-TB patients $(12,13)$, and the genetic deficiencies of immune effectors such as TNF and iNOS have confirmed its importance as critical for immune protection against tuberculosis in the CNS $(14,15)$.

Homeostasis is crucial for neural activities; therefore, the interactions between the CNS and immune systems must be tightly regulated to maintain balance between immune and neural functions. This is supported by the blood-brain barrier which separates the CNS from the regular systemic blood circulation that protects the CNS from the milieu of the periphery. However, research findings 
have demonstrated that both resident and infiltrating immune cells participate actively in immune responses in the CNS, which upon activation may secrete cytokines including TNF (16-20). Also, using animal models of TNF deficient or overexpression, we and others have directly demonstrated the important role of TNF in pathogenesis and protective immunity during CNS-TB infection $(15,21)$.

In the brain, TNF is synthesized by both immune (including infiltrating cells) and non-immune cells (including neurons). Microglial cells, as the resident immune cells of the CNS, are thought to be the first line of defense and main source of TNF during CNS-TB $(18,22-24)$. The peripheral T cells have the ability to produce TNF along with interferon- $\gamma$ (IFN- $\gamma$ ) that acts in both innate and specific cell-mediated immunities during mycobacterial infection (25-27). Moreover, intracerebral BCG infection induces infiltration of IFN- $\gamma$ and TNF producing $\mathrm{T}$ cells into the CNS $(18,28)$. In a previous study, we reported on the prominence of TNF-mediated innate immunity during cerebral tuberculosis while neuron-derived TNF was found to be dispensable (15). Therefore, further identifying the cellular sources of TNF that contribute to the pathogenesis and immunity in the context of CNS-TB is of significant interest. In this study we investigated the functions of TNF produced collectively by myeloid and $\mathrm{T}$ cells in mediating immune protection against cerebral M. tuberculosis infection. We used mice deficient for both myeloid- and T cell-derived TNF $\left(\mathrm{MT}^{-\mathrm{TNF}^{--}}\right)$and investigated outcomes after intracerebral M. tuberculosis infection in comparative studies with TNF floxed wild-type $\left(\mathrm{TNF}^{\mathrm{f} / \mathrm{f}}\right)$ and complete TNF-deficient $\left(\mathrm{TNF}^{-/-}\right)$mice. We demonstrate the significance of TNF production by myeloid and T cells for controlling CNS-TB infection.

\section{MATERIALS AND METHODS}

\section{Mice}

All mouse strains, including TNF floxed wild type $\left(\mathrm{TNF}^{\mathrm{f} / \mathrm{f}}\right)$,

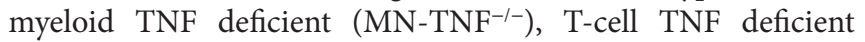
$\left(\mathrm{T}_{-} \mathrm{TNF}^{-/-}\right)$, myeloid and T-cell TNF deficient $\left(\mathrm{MT}^{\mathrm{T}} \mathrm{TNF}^{-/-}\right.$), and complete $\mathrm{TNF}$ deficient $\left(\mathrm{TNF}^{-/}\right.$) were previously described $(4,15,19,29)$ and maintained under specific pathogen-free conditions at the research animal facility of the University of Cape Town. Adult mice were PCR genotyped and used between 6 and 12 weeks of age. Infected mice were maintained under biosafety level 3 conditions. All animal procedures were approved by the Animal Research Ethics Committee, University of Cape Town, in accordance with the South African National Standard.

\section{Intracerebral Infection}

Mycobacterium tuberculosis strain $\mathrm{H} 37 \mathrm{Rv}$ was grown at $37^{\circ} \mathrm{C}$ in Middlebrook $7 \mathrm{H} 9$ broth containing $10 \%$ OADC and $0.5 \%$ Tween- 80 until log phase, then aliquoted and stored at $-80^{\circ} \mathrm{C}$. A frozen aliquot was thawed, passed 30 times through 29 gauge needle and diluted in sterile saline. Intracerebral infection was performed using a stereotaxic approach of directly injecting H37Rv into the cerebral cortex. Prior to inoculation, a small burr hole was constructed anterior to the bregma and to the left of the midline in the skull exposing the dura mater. Mice were inoculated intracerebrally with $1 \times 10^{4}-1 \times 10^{5}$ colony forming units (CFUs) of $M$. tuberculosis $\mathrm{H} 37 \mathrm{Rv}$ using Hamilton syringe (Gastight no. 1701, Switzerland). The burr hole was sealed with bone wax and the skin sutured.

\section{Colony Enumeration Assay}

Bacterial burdens in the brains, lungs, and spleens of infected mice were determined at specific time points after infection with $M$. tuberculosis. Organs were weighed and homogenized in $0.04 \%$ Tween 80 saline. Also, 10-fold serial dilutions of organ homogenates were plated in duplicates on Middlebrook $7 \mathrm{H} 10$ (Becton, Dickinson and Company) agar containing 10\% OADC (Life Technologies, Gaitherburg, MD, USA), and incubated at $37^{\circ} \mathrm{C}$ for $19-21$ days. The concentration of M. tuberculosis was then determined by counting the CFUs.

\section{Flow Cytometry}

Mouse brains were collected to generate single cell suspensions. Non-specific binding to cells was blocked through incubation with $\alpha$ Fc $\gamma$ RIII $(1 \mathrm{mg} / \mathrm{ml}$ of rat $\alpha$-mouse CD32/16c). The following antibodies were used to stain the surface markers: CD11b-PerCP-Cy5-5 (Clone M1/70), CD11c-Alexa 700 (Clone HL3), CD45-APC (Clone 30- F11), CD80-FITC (16-10 A1), CD86-V450 (Clone GL1), MHCII/(I-A/I-E)-PE (M5/114.15.2), CD3?-Pacific Blue, CD4-Alexa 700, and CD8-PerCP-Cy5.5. All antibodies were from $\mathrm{BD}$ Pharmingen ${ }^{\mathrm{TM}}$ and $\mathrm{BD}$ Horizon $^{\mathrm{TM}}$. After staining, cells were washed and fixed, then analyzed on BD LSR Fortessa (Beckton Dickinson) flow cytometer using Cell Quest software.

\section{Quantification of Chemokines and Cytokines}

Supernatants from brain homogenates were prepared for cytokine and chemokine measurement by enzyme-linked immunosorbent assay (ELISA) after 3 weeks subsequent to intracerebral M. tuberculosis infection. The chemokines MCP-1, MIP-1 $\alpha$, and RANTES; and the cytokines IFN- $\gamma$, IL-2, IL-6, IL-12p70, and TNF (R\&D Systems, Germany) were measured using commercially available ELISA reagents according to the manufacturer's instructions. Chemokine and cytokine concentrations were measured by absorbance using a Versamax Microplate Reader (Molecular Devices, LLC, CA, USA) with SoftMax software.

\section{Statistical Analysis}

The data are presented as the mean \pm SEM. Statistical analysis was performed by two-way ANOVA and one-tailed $t$-test. For all tests, a $p$-value of $\leq 0.05$ was considered significant.

\section{RESULTS}

\section{TNF Produced by Myeloid Cell and T-Cell Are Required for Protection against $M$. tuberculosis Infection in the Brain (Similar to $\mathrm{TNF}^{-/-}$)}

Myeloid and T-cells contribute significantly to the pathogenesis of pulmonary tuberculosis $(4,30)$. To address the contribution 
of TNF derived from myeloid and T cells in protective immunity against CNS-TB, we intracerebrally challenged the mice with $M$. tuberculosis and compared disease progression in various cell-specific TNF-deficient mice, including myeloid specific $\left(\mathrm{MN}^{-\mathrm{TNF}^{-/-}}{ }^{-}\right.$, T-cell specific $\left(\mathrm{T}_{-} \mathrm{TNF}^{-/-}\right)$, and TNF deficient in both myeloid and T-cells $\left(\mathrm{MT}_{\mathrm{TNF}}{ }^{-/-}\right)$. We found that $\mathrm{MN}-\mathrm{TNF}^{-/-}$ and $\mathrm{T}_{-} \mathrm{TNF}^{-/-}$mice survived the infection similar to wild-type $\mathrm{TNF}^{\mathrm{f} / \mathrm{f}}$ mice (Table 1); therefore, TNF deficiency in either myeloid cells or T cells had no effects on the overall protection against cerebral tuberculosis. Interestingly, the $\mathrm{MT}^{-} \mathrm{TNF}^{-/-}$mice succumbed to the infection similar to the complete-deficient $\mathrm{TNF}^{-/-}$mice (Table 1; Figures 1A,B). As previously reported (15), $\mathrm{TNF}^{-/-}$ mice were highly susceptible to cerebral $M$. tuberculosis infection resulting in rapid weight loss and death by 3 weeks postinfection. In comparison to $\mathrm{TNF}^{-/-}$mice, $\mathrm{MT}^{-\mathrm{TNF}^{-/}}$mice were similarly highly susceptible and rapidly succumbed to infection with $>20 \%$ body weight loss (Figures 1A,B).

To further investigate the synergistic role of myeloid and T-cell-derived TNF to control cerebral bacilli replication, we assessed bacterial burden in the brains of $M$. tuberculosis infected $\mathrm{TNF}^{\mathrm{f/f}}, \mathrm{MT}^{\mathrm{TNNF}}{ }^{-/-}$, and $\mathrm{TNF}^{-/-}$mice (Figure 1C). $\mathrm{MT}^{-\mathrm{TNF}^{-/-}}$ and $\mathrm{TNF}^{-1}$ mice exhibited similar significant increases in cerebral bacilli burdens compared to $\mathrm{TNF}^{\mathrm{f} / \mathrm{f}}$ mice at day 14 $(p<0.001)$ and day $21(p<0.01)$ postinfection. We next assessed the extent of dissemination of bacilli from the brain by measuring the levels of pulmonary and splenic bacterial burden (Figure 1C). MT-TNF ${ }^{-1}$ mice showed mycobacterial dissemination similar to the $\mathrm{TNF}^{-/-}$mice in both lungs and spleens which were $1-2 \log _{10}$ higher than $\mathrm{TNF}^{\mathrm{f} / \mathrm{f}}$ wild-type mice. Thus, these data demonstrate that myeloid and T cell-derived TNF is a collective requirement for cerebral immune protection and control of $M$. tuberculosis replication.

\section{Myeloid Cell and T-Cell-Derived TNF Are Essential to Control Pathology and Inflammation during Cerebral Tuberculosis} We next examined the synergistic role of myeloid and T-cellderived TNF to control cerebral inflammation by analysis of brain histopathology in M. tuberculosis-infected mice at 3 weeks postinfection (Figure 2). In the brain sections taken from $\mathrm{TNF}^{\mathrm{f} / \mathrm{f}}$ and $\mathrm{TNF}^{-/-}$mice, we observed similar degrees of inflammation as to what we reported previously (15). The cerebral inflammation was controlled in $\mathrm{TNF}^{\mathrm{f} / \mathrm{f}}$ mice, suggested by the predominant

TABLE 1 | Clinical parameters of cerebral tuberculosis in various cellspecific tumor necrosis factor (TNF)-deficient mice.

\begin{tabular}{|c|c|c|c|c|}
\hline & \multicolumn{2}{|c|}{ Day 25} & \multicolumn{2}{|c|}{ Day 105} \\
\hline & Mortality (\%) & $\begin{array}{c}\text { Body weight } \\
\text { change (\%) }\end{array}$ & Mortality (\%) & $\begin{array}{l}\text { Body weight } \\
\text { change (\%) }\end{array}$ \\
\hline $\mathrm{TNF}^{\mathrm{f} / \mathrm{f}}$ & $0(0 / 27)$ & 2.8 & $0(0 / 27)$ & 4.6 \\
\hline $\mathrm{MN}-\mathrm{TNF}^{-/-}$ & $0(0 / 20)$ & 1.9 & $0(0 / 20)$ & 2.9 \\
\hline T-TNF $-/-$ & $0(0 / 22)$ & 1.3 & $4.5(1 / 22)$ & 3.4 \\
\hline MT-TNF-/- & $94.1(16 / 17)$ & -26.8 & - & - \\
\hline $\mathrm{TNF}^{-/-}$ & $91.7(22 / 24)$ & -21.4 & - & - \\
\hline
\end{tabular}

The data are pooled of at least three independent experiments. lymphocytic infiltration found in the choroid plexus and ventricles of $\mathrm{TNF}^{\mathrm{f} / \mathrm{f}}$ brains. In contrast, both $\mathrm{MT}^{-\mathrm{TNF}^{-/}}$and $\mathrm{TNF}^{-/-}$mice exhibited severe neuropathology and uncontrolled inflammation where cellular infiltration was extended to the periventricular tissue. Similar to $\mathrm{TNF}^{-/-}$mice, $\mathrm{MT}^{-\mathrm{TNF}^{-/-}}$mice also had foci of necrosis in the brain tissue where acid fast bacilli were largely found.

The neuropathology observed in the $\mathrm{MT}^{-\mathrm{TNF}^{-/}}$mice suggested defective TNF-mediated cellular recruitment and innate immune responses in response to $M$. tuberculosis challenge. We, therefore, quantified microglia $\left(\mathrm{CD} 11 \mathrm{~b}^{+} \mathrm{CD} 45^{\text {low }}\right)$ and macrophages $\left(\mathrm{CD} 11 \mathrm{~b}^{+} \mathrm{CD} 45^{\mathrm{high}}\right)$ in the brain and evaluated activation status of these innate immune cells subsequent to 3 weeks cerebral $M$. tuberculosis infection. The flowcytometric analysis revealed significantly higher $(p<0.05)$ frequencies and absolute cell numbers of microglia and macrophages in both $\mathrm{TNF}^{-1-}$ and

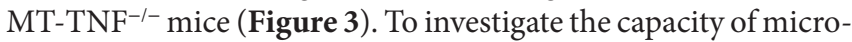
glia and macrophages to present antigen and activate lymphocytes, we analyzed the expression of MHCII, CD80, and CD86. Apart from similar levels of CD86 in all three mouse strains (data not shown), we observed significantly lower $(p<0.01)$ expression of CD80 and MHCII in MT-TNF ${ }^{-/-}$compared to $\mathrm{TNF}^{\mathrm{f} / \mathrm{f}}$ mice (Figure 3).

Therefore, myeloid cell and T-cell-derived TNF were required to regulate CNS inflammation during $M$. tuberculosis infection; moreover, it determined the quality of the innate immune response.

\section{Absence of TNF on Myeloid and T Cell Renders Defective T-Cell Responses during Cerebral Tuberculosis}

To explore whether the myeloid- and T-cell-derived TNF alter influx of $\mathrm{T}$ cells into the brain, we quantified $\mathrm{CD}^{+} \mathrm{CD}^{+}$and $\mathrm{CD}^{+}{ }^{+} \mathrm{CD}^{+} \mathrm{T}$ cell recruitment in the $\mathrm{TNF}^{\mathrm{f} / \mathrm{f}}, \mathrm{MT}^{-\mathrm{TNF}^{-/-}}{ }^{\text {, and }}$ $\mathrm{TNF}^{-/-}$mouse brains after $M$. tuberculosis cerebral infection. We observed an overall increase in the frequencies of $\mathrm{CD}^{+} \mathrm{CD} 4^{+}$ and $\mathrm{CD}^{+} \mathrm{CD}^{+} \mathrm{T}$ cells in the brains of all strains over 3 weeks postinfection, especially more in $\mathrm{MT}^{-\mathrm{TNF}^{-/}}$and $\mathrm{TNF}^{-/-}$at all time points (data not shown). At 3 weeks postinfection, the frequency of $\mathrm{CD}^{+} \mathrm{CD}^{+}$cells in the $\mathrm{MT}^{-\mathrm{TNF}^{-/-}}$and $\mathrm{TNF}^{-/-}$mouse brains was more than twofold higher compared to $\mathrm{TNF}^{\mathrm{f} / \mathrm{f}}$ mice (Figure 4A). The frequencies of $\mathrm{CD}^{+} \mathrm{CD}^{+} \mathrm{T}$ cells in $\mathrm{MT}^{-\mathrm{TNF}^{-/}}$ and $\mathrm{TNF}^{-1-}$ mice at week 3 postinfection were found more than threefold higher compared with $\mathrm{TNF}^{\mathrm{f} / \mathrm{f}}$ mice. Comparatively, $\mathrm{MT}^{-\mathrm{TNF}^{-/}}$and $\mathrm{TNF}^{-/-}$mice exhibited similar frequencies of $\mathrm{CD}^{+} \mathrm{CD}^{+}$and $\mathrm{CD}^{+} \mathrm{CD}^{+} \mathrm{T}$ cells in the brain (Figure 4A). When assessing the absolute cell numbers of infiltrating cells at 3 weeks postinfection, we found equivalent numbers of $\mathrm{CD}^{+}{ }^{+} \mathrm{CD} 4^{+}$(Figure 4B) and $\mathrm{CD}^{+} \mathrm{CD}^{+}$(Figure 4C) $\mathrm{T}$ cells in the $\mathrm{MT}_{-} \mathrm{TNF}^{-/-}$and $\mathrm{TNF}^{-/-}$mice, which were significantly higher compared to $\mathrm{TNF}^{\mathrm{f} / \mathrm{f}}$ mice. To further examine the effector function of these $\mathrm{T}$ cells, we analyzed the expression levels of CD44. The percentage of $\mathrm{CD}^{+} \mathrm{CD}^{+}$(Figure 4D) and $\mathrm{CD}^{+} \mathrm{CD}^{+}$ (Figure 4E) T cells expressing CD44 in both $\mathrm{MT}^{-\mathrm{TNF}^{-/}}$and $\mathrm{TNF}^{-/-}$mice were significantly higher $(p<0.001)$ than in $\mathrm{TNF}^{\mathrm{f} / \mathrm{f}}$ mice at week 3 postinfection. Therefore, these data suggest that 

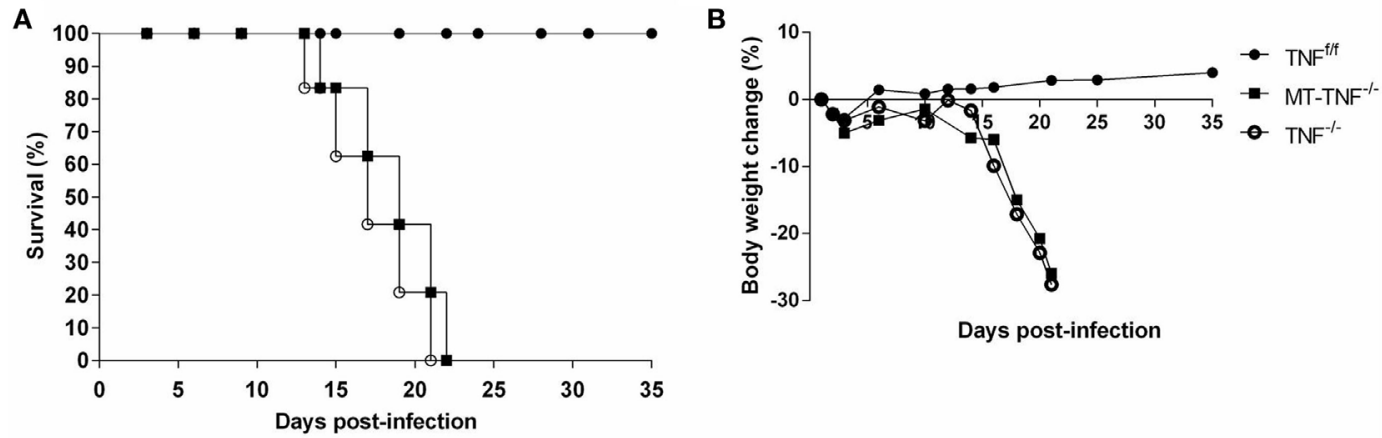

C

2 weeks
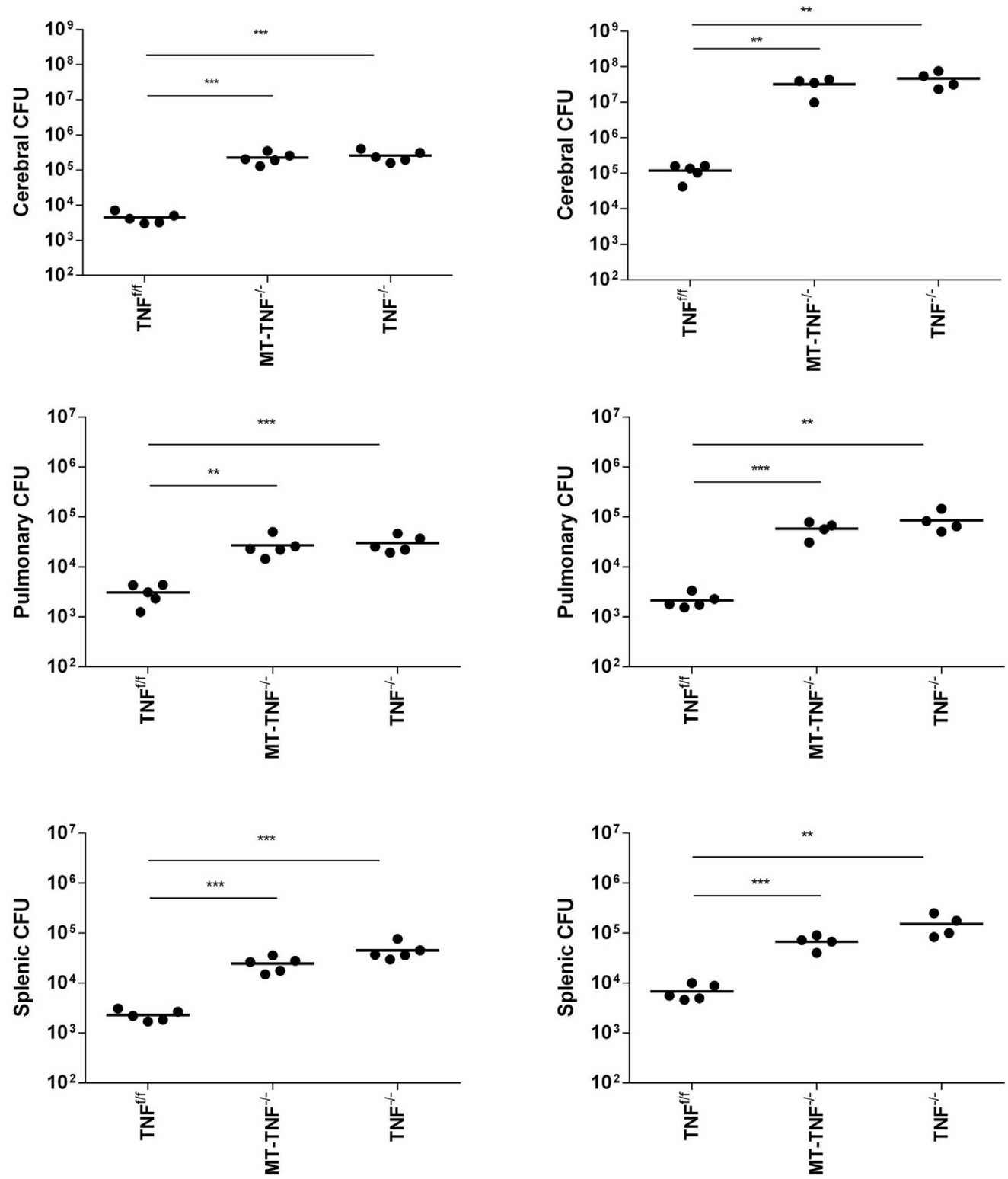

FIGURE 1 | Continued 
FIGURE 1 | Continued

Tumor necrosis factor (TNF) produced by myeloid and T-cells is essential for protection against Mycobacterium tuberculosis infection in the brain. $\mathrm{TNF}^{\mathrm{f} / \mathrm{f}}$ (black circle), $\mathrm{MT}^{-\mathrm{TNF}^{-/-}}$(black square) and $\mathrm{TNF}^{-/-}$(clear circle) mice were infected with $\mathrm{M}$. tuberculosis $\mathrm{H} 37 \mathrm{Rv}$ at a dose of $1 \times 10^{4}-1 \times 10^{5} \mathrm{CFU}^{-\mathrm{brain}}$ by intracerebral inoculation. Mortality (A) and body weight changes (B) were measured and recorded for the experimental duration ( $n=5-7$ mice/group). (C) Bacterial burdens in brains, spleens, and lungs were determined at day 14 and 21 postinfection. These data were one representative out of three to five independent experiments $\left({ }^{\star} p \leq 0.05,{ }^{\star \star} p \leq 0.01\right.$, and $\left.{ }^{\star \star \star} p \leq 0.001\right)$.
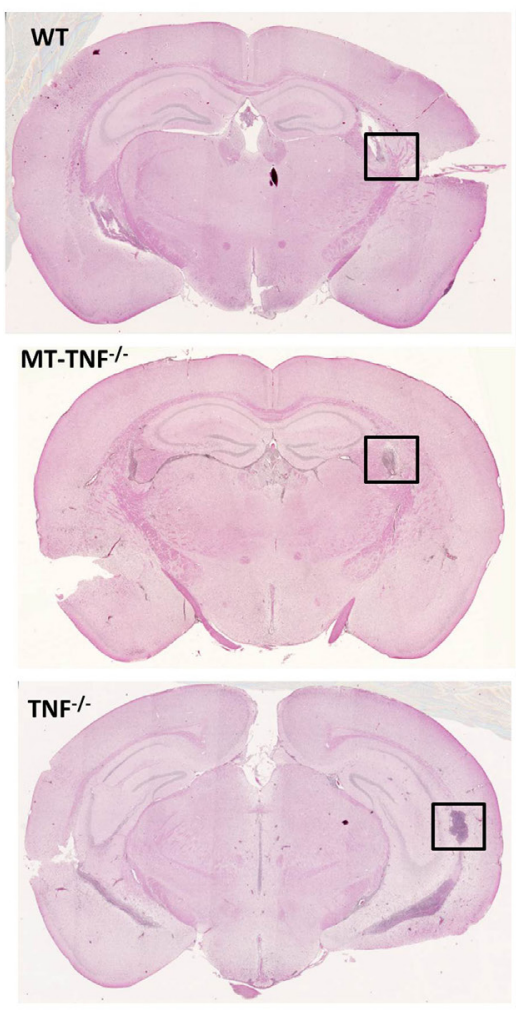
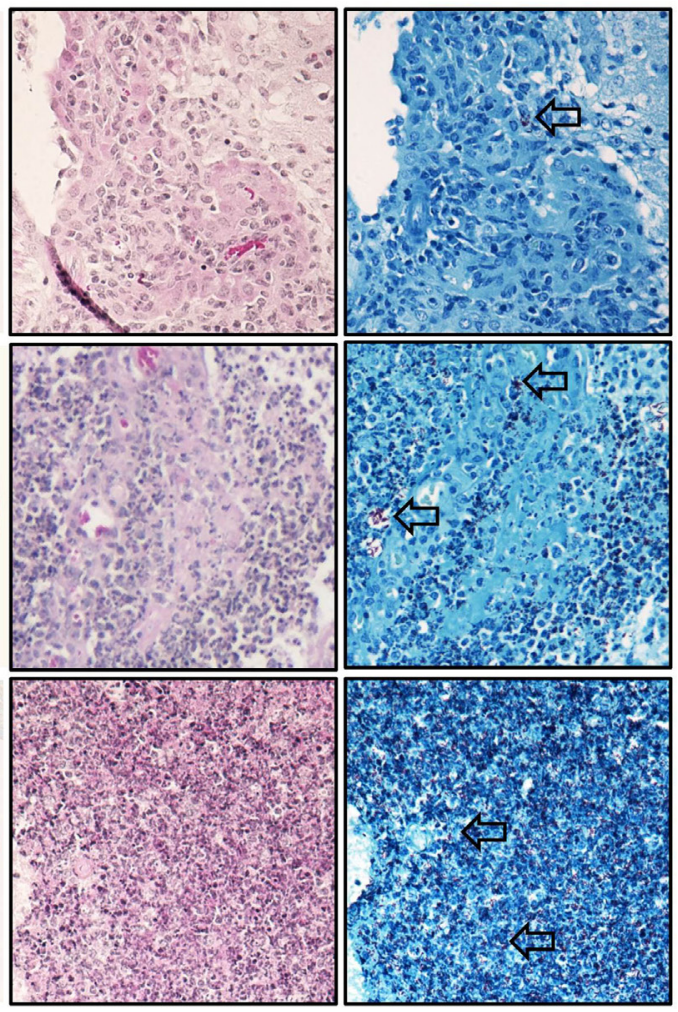

FIGURE 2 | Myeloid cells and T-cells are important source for tumor necrosis factor (TNF)-dependent pathology during cerebral tuberculosis.

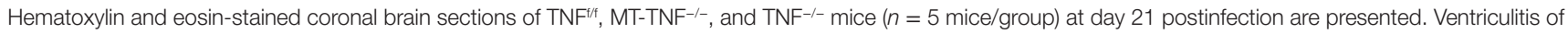
the choroid plexus accompanied by necrosis (box) are observed. Corresponding Ziehl-Neelsen stain revealed acid-fast bacilli (arrows). The images are representatives of three to five independent experiments.

in the absence of myeloid and T cell-derived TNF, as well as in the complete ablation of TNF, the overall $\mathrm{T}$ cell response was deregulated by means of $\mathrm{T}$ cell influx and activation.

\section{Differential Regulation of Cytokines and Chemokines by Myeloid and T-Cell- Derived TNF during Cerebral $M$. tuberculosis Infection}

To further dissect the mechanism behind the increased innate immune cell recruitment and $\mathrm{T}$ cell development, we analyzed the levels of cytokines and chemokines induction in response to $M$. tuberculosis infection. We measured concentrations of the cytokines, TNF, IFN- $\gamma$, IL-2, IL-6, and IL-12p70, as well as the chemokines, MIP-1 $\alpha$, MCP-1, and RANTES, in the brain homogenates of $\mathrm{TNF}^{\mathrm{f} / \mathrm{f}}, \mathrm{MT}^{-\mathrm{TNF}^{-/}}$, and $\mathrm{TNF}^{-/-}$mice after 3 weeks intracerebral infection (Figure 5).

As expected, no TNF production was detected in $\mathrm{TNF}^{-1-}$ mice and the induction of TNF in $\mathrm{TNF}^{\mathrm{f} / \mathrm{f}}$ mice confirmed its requirement as part of protective immune responses. TNF expression in $\mathrm{MT}^{-\mathrm{TNF}^{-/}}$mice indicated that TNF in the 3 weeks $M$. tuberculosis-infected brain were mostly contributed by myeloid and T cells. Similar to the reduced TNF production of $\mathrm{MT}^{-\mathrm{TNF}^{-1-}}$ mice, IL-2 and IL-12p70 in $\mathrm{MT}^{-\mathrm{TNF}^{-/-} \text {mouse }}$ brains were also significantly lower compared to $\mathrm{TNF}^{\mathrm{f} / \mathrm{f}}$ mice. Alternatively, we observed increased levels of IFN- $\gamma$ and IL-6 production in $\mathrm{MT}^{-\mathrm{TNF}^{-/}}$mice, which were significantly higher than the $\mathrm{TNF}^{\mathrm{f} / \mathrm{f}}$ mice. We found similar expression levels in both MT-TNF ${ }^{-1-}$ and $\mathrm{TNF}^{-/-}$infected brains, which were significantly higher $(p<0.01)$ than the $\mathrm{TNF}^{\mathrm{f} / \mathrm{f}}$-infected brains. 
A
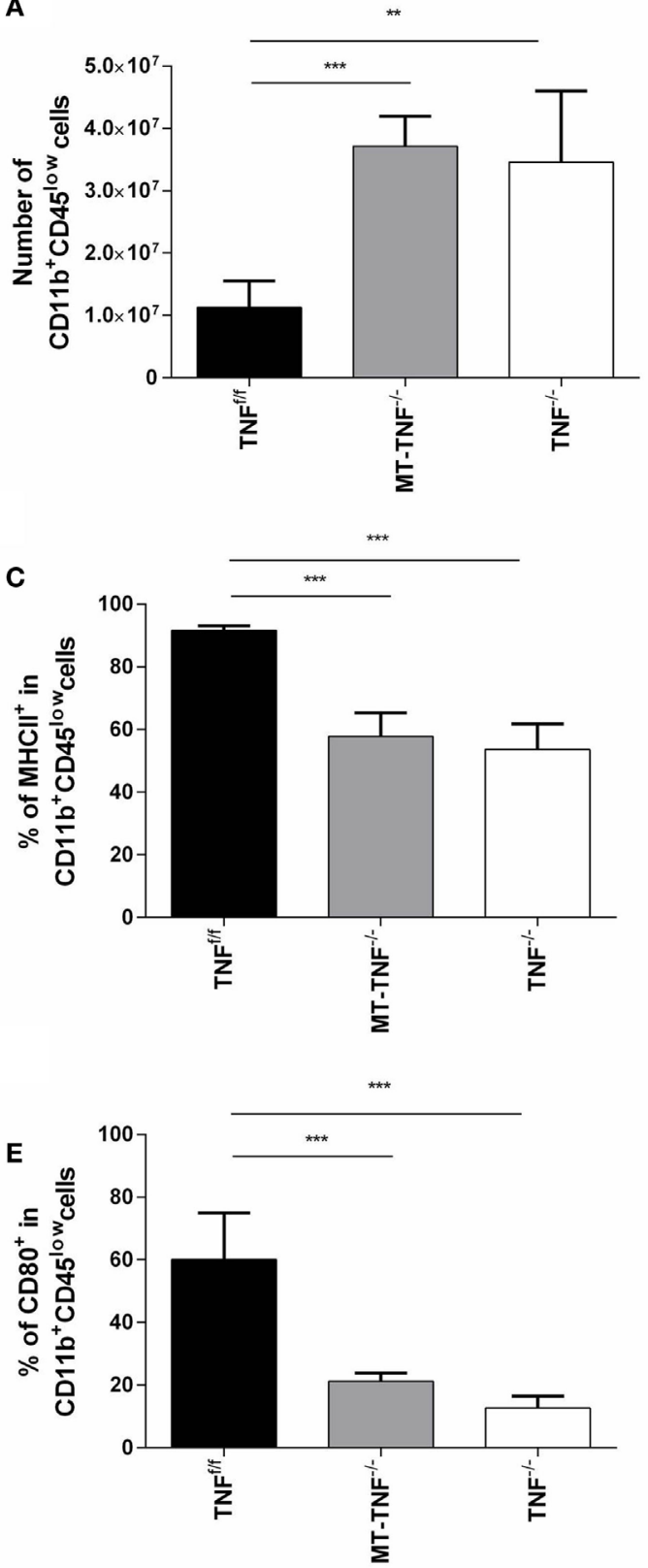

B

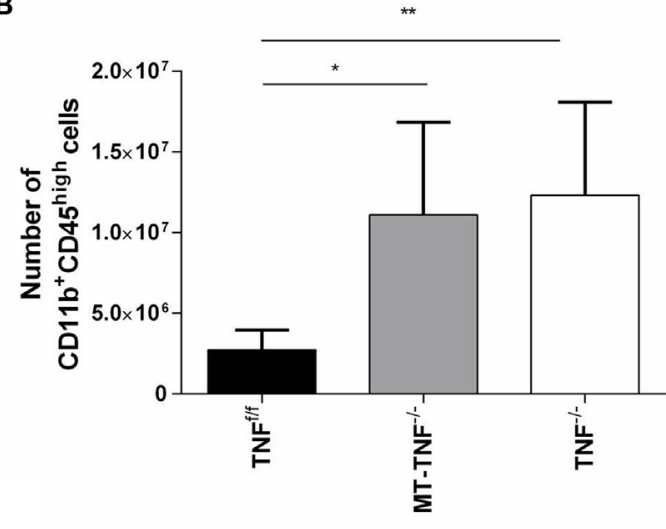

D
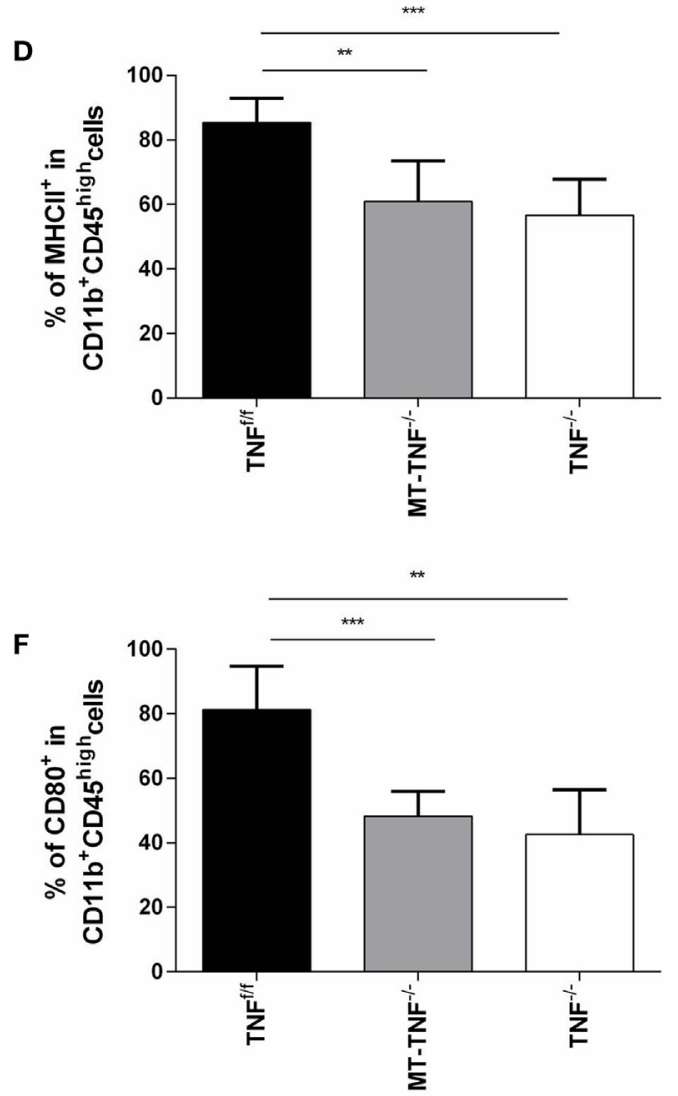

FIGURE 3 | Tumor necrosis factor (TNF) production by myeloid cells and T-cells is required for activation and regulation of innate immunity during cerebral tuberculosis. TNF ${ }^{\text {iff }}$ (black), MT-TNF-/- (gray), and $\mathrm{TNF}^{-/-}$(clear) mice were infected with Mycobacterium tuberculosis H37Rv at a dose of $1 \times 10^{4}-$ $1 \times 10^{5} \mathrm{CFU} /$ brain by intracerebral inoculation. The number of $(\mathbf{A}) \mathrm{CD} 11 \mathrm{~b}{ }^{+} \mathrm{CD} 45^{\text {low }}$ microglia and $(\mathbf{B}) \mathrm{CD} 11 \mathrm{~b}^{+} \mathrm{CD} 45^{\text {high }}$ macrophages and the frequency of $(\mathbf{C}, \mathbf{D})$ MHC II and (E,F) CD80 expression was analyzed by flow cytometry at day 21 postinfection. Data (mean \pm SEM of five mice) are representative of three repeat experiments $\left({ }^{*} p \leq 0.05,{ }^{* *} p \leq 0.01\right.$, and $\left.{ }^{* * *} p \leq 0.001\right)$.

Therefore, data showed that myeloid and T cell-derived TNF have differential effects on cytokine and chemokine production during cerebral M. tuberculosis infection. These results also illustrate that deletion of TNF from myeloid and T cells rendered an uncontrolled increase of IFN- $\gamma$ and IL- 6 protein and reduced IL- 2 and IL-12p70 production. The results further demonstrate that ablation of TNF in myeloid and T cells resulted in an impaired chemoattractant response during cerebral M. tuberculosis infection.

\section{DISCUSSION}

It has been demonstrated that elevated levels of TNF are associated with TB meningitis and tuberculoma $(12,13)$. More recently, 

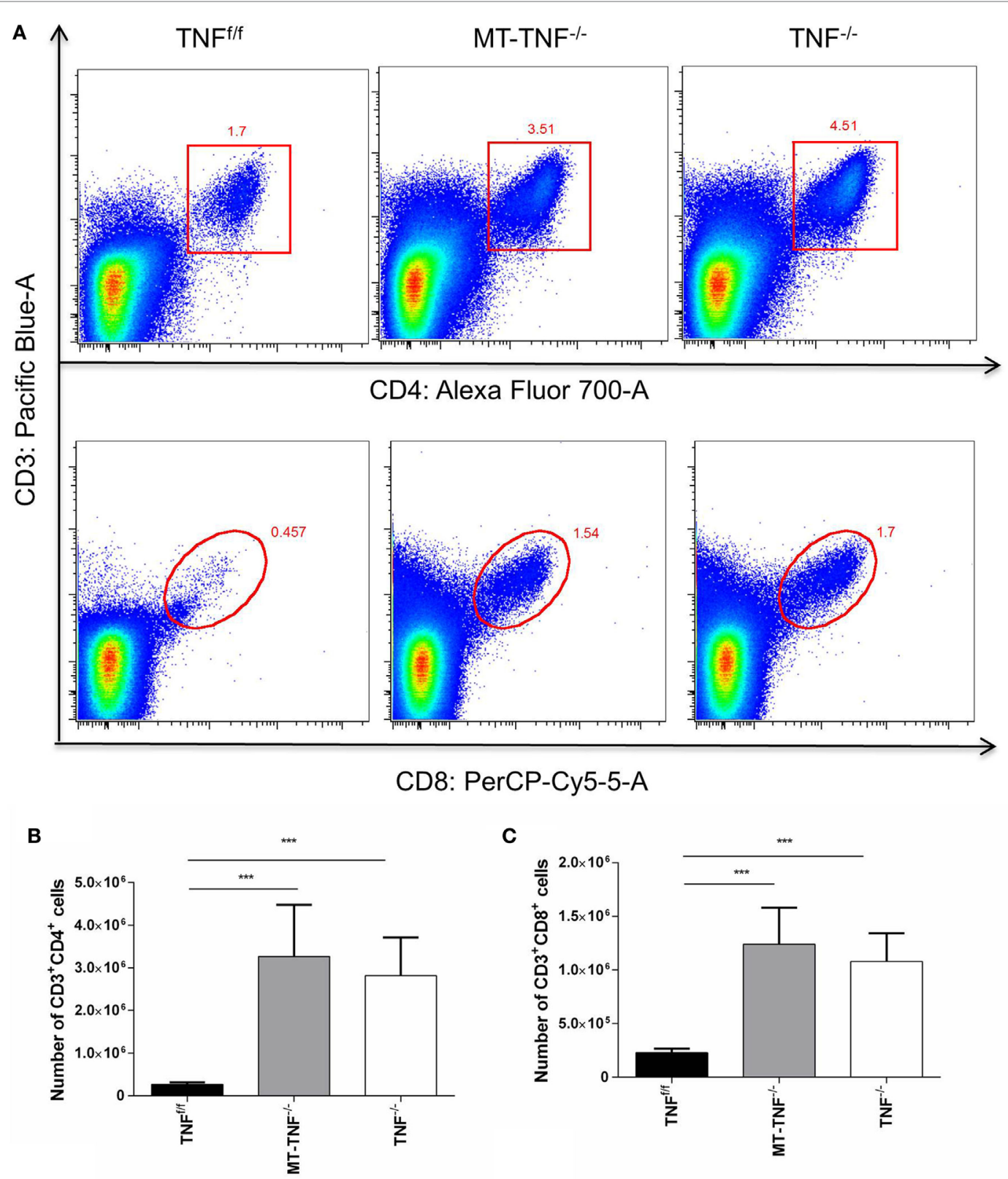

C
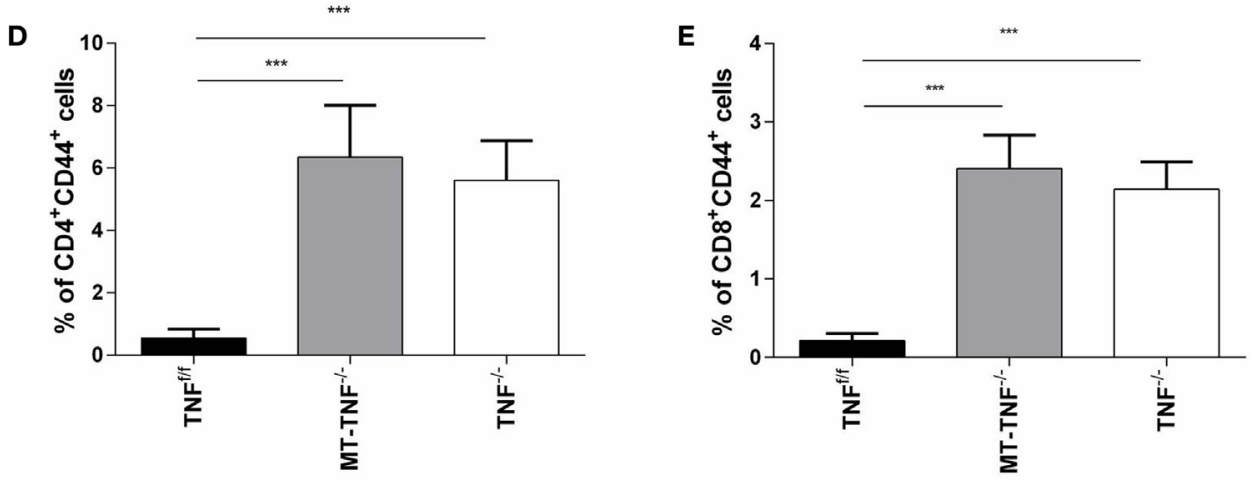
FIGURE 4 | Continued

Cerebral tuberculosis-induced T-cell response is dependent on the myeloid and T-cells-derived tumor necrosis factor (TNF). (A) Representative FACS

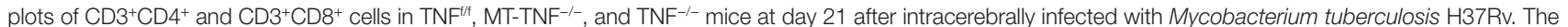
number of (B) $\mathrm{CD}^{+} \mathrm{CD} 4^{+}$and (C) $\mathrm{CD}^{+}{ }^{+} \mathrm{CD} 8^{+}$, and the frequency of (D) $\mathrm{CD}^{+}{ }^{+} \mathrm{CD} 44^{+}$and (E) $\mathrm{CD} 8{ }^{+} \mathrm{CD} 44^{+}$expression, was analyzed by flow cytometry at day 21 postinfection. Data (mean \pm SEM of five mice) are representative of three repeat experiments $\left({ }^{\star} p \leq 0.05,{ }^{\star \star} p \leq 0.01\right.$, and $\left.{ }^{\star \star *} p \leq 0.001\right)$.
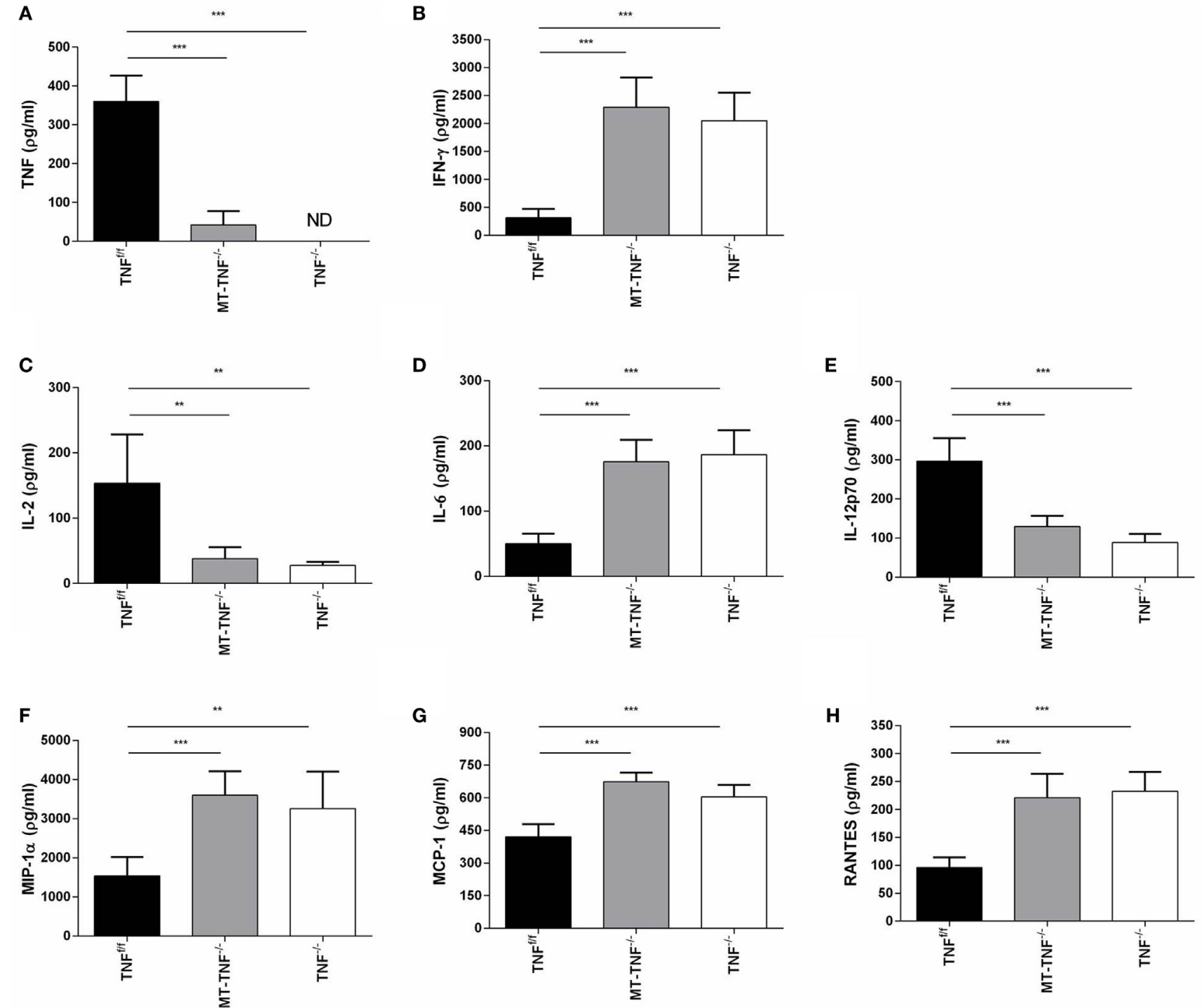

FIGURE 5 | Myeloid and T-cells-derived tumor necrosis factor (TNF) regulates synthesis of cytokine and chemokines. (A) TNF, (B) IFN- $\gamma$, (C) IL-2, (D)

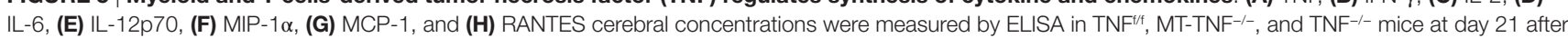
intracerebrally infected with Mycobacterium tuberculosis H37Rv. Data (mean \pm SEM of five mice) are representative of at least three repeat experiments ( ${ }^{\star} p \leq 0.05$, ${ }^{* *} p \leq 0.01$, and $\left.{ }^{* \star *} p \leq 0.001\right)$

data from human, mouse, and zebrafish indicate that a relative deficiency of TNF results in destructive immunopathology during CNS-TB infection $(6,15)$. This study has shown that TNF is absolutely required for protective host immune responses during CNS-TB and is in agreement with the previous reports.
In the CNS, TNF is produced by immune and non-immune cells (20); however, the mechanisms by which cell-specific TNF acts to control CNS-TB and cellular recruitment to the infection site are not clearly defined. In this study, $\mathrm{MT}^{-\mathrm{TNF}^{-/-}}$mice were highly susceptible to cerebral tuberculosis infection. Therefore, 
we have demonstrated ablation of TNF from myeloid and T cells resembled complete ablation of TNF, suggesting that myeloid and $\mathrm{T}$ cells are major sources of TNF in mediating immune protection against CNS-TB. It also provides important evidence that synergistic activity of TNF derived from myeloid cells and T cells is required for optimum protection.

As part of the host-pathogen interaction, M. tuberculosis induces a TNF-dependent host immune response orchestrated from various cell types $(4,24,31,32)$. TNF signaling through TNF receptors (TNFRp55 and TNFRp75) forms an integral component in protective immunity against tuberculosis $(1,30,33)$. To dissect the cellular contribution to TNF functions, Grivennikov and colleagues were first to generate and report the cell-specific TNF-deficient mice. They used Cre-loxP recombination system to target $\mathrm{TNF}$ gene and generated $\mathrm{TNF}^{\mathrm{f} / \mathrm{f}}$ and $\mathrm{TNF}^{-/-}$mouse together with a panel of cell-specific TNF-deficient mice and successfully demonstrated selective and efficient ablation of TNF in myeloid cells or/and lymphocytes of these mice by ELISA and intracellular TNF staining (29). The use of cell-specific gene-deficient mice has yielded insight into regulatory roles of cell type-specific expression of TNF and TNFRp55 in immune control during mycobacterial infection $(4,15,29,30)$. Previously, we have identified myeloid and lymphoid cells as critical sources of TNF for control of pulmonary M. tuberculosis infection; while myeloid TNF is required for early innate immune protection, $\mathrm{T}$ cell-derived TNF has a prominent role for chronic infection. Moreover, myeloid and T cell TNF act collectively in pulmonary tuberculosis resembling the effect of overall TNF (4). This distinct cellular contribution of TNF has also been seen in neuroinflammation. Kruglov and colleagues have shown that myeloid and $\mathrm{T}$ cells are the critical source of TNF during EAE, where the $\mathrm{MT}_{\mathrm{TNF}}{ }^{-/}$mice recapitulated the pathology and disease progression seen in complete TNF-deficient mice (19). Despite the different pathogenesis in EAE and CNS-TB, our current study suggested that myeloid cells and $\mathrm{T}$ cell are the main source of total TNF production in the brain at day 21 postinfection. Although, there are differences in organ-specific makeup between the brain and lung, the overall results of $\mathrm{MT}^{\mathrm{T}} \mathrm{TNF}^{-/-}$mice in CNS-TB are consistent with those seen in pulmonary TB (4), indicating that the underlying immune protective mechanisms in both pulmonary and CNS-TB model are similar.

During pulmonary $M$. tuberculosis infection, the innate myeloid cells are crucial for immune protection in a TNF/ TNFRp55-dependent manner. The absence of TNF or TNFRp55 in macrophages and dendritic cells dramatically impaired the host responses to acute pulmonary $M$. tuberculosis infection $(4,30)$. In the CNS, microglia are considered the resident macrophages and shared the same myeloid origin as the peripheral monocytes during early development; however, emerging evidence suggests that microglia differ considerably from the circulating macrophages $(34,35)$. Some concerns have been raised with respect to the use of Cre-LysM system to target gene deletion specifically in microglia in which Cre transgene is constitutively expressed in the lysozyme loci of myeloid cells. Different data were reported on the percentage of gene recombination/deletion in microglia (36-38); however, it was shown that the difference in efficiency of gene recombination lies in the active states of microglia (38).
In this study, we have analyzed the numbers and the functionality of $\mathrm{CD} 11 \mathrm{~b}^{+} \mathrm{CD} 45^{\text {low }}$ and $\mathrm{CD} 11 \mathrm{~b}^{+} \mathrm{CD} 45^{\text {high }}$ cells; however, it is not within the scope of our study to differentiate the TNF contribution from resting to active microglia. We have shown the ability of myeloid-specific TNF-deficient mice to survive the cerebral $M$. tuberculosis infection; however, we do not discriminate the important role of microglia as the main source of TNF in the brain during CNS-TB $(18,22-24)$. Although we did not observe

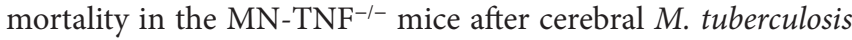
infection, it is likely that TNF production from other cell-types compensate the effects $(4,18,20)$. To gain more insight on TNF production by other cell types in the CNS, we have recently generated neuron-specific TNF-deficient mice $\left(\mathrm{Ns}^{\left.-\mathrm{TNF}^{-/}\right)}\right.$to study the role of neuron-derived TNF in CNS-TB (15). In our previous report, we have demonstrated specific TNF ablation in the neurons of Ns- $\mathrm{TNF}^{-/-}$mouse by intracellular TNF staining that shows TNF production in the $\mathrm{TNF}^{\mathrm{f} / \mathrm{f}}$ neurons, but not in the $\mathrm{Ns}^{-} \mathrm{TNF}^{-/-}$and $\mathrm{TNF}^{-/-}$neurons. While neuron-derived TNF is dispensable in protective immunity against CNS-TB, neurons contribute to TNF production during CNS-TB (15). Astrocytes as the most abundant glial cell population are also capable of secreting TNF in response to various stimuli (39-41). Although astrocytes have been shown to internalize $M$. tuberculosis bacilli (23), the roles of reactive astrocytes during the response to $M$. tuberculosis infection are only beginning to be elucidated.

Unlike the $\mathrm{MN}-\mathrm{TNF}^{--}$mice, uncontrolled cellular recruitment and poor immune activation in $\mathrm{MT}^{-\mathrm{TNF}^{-1}}$ mice have provided conclusive evidence that collective TNF production by myeloid and $\mathrm{T}$ cells is critical in immune regulation during CNS-TB infection. Taken together the survival of $\mathrm{MN}_{-} \mathrm{TNF}^{-/-}$and $\mathrm{T}_{-} \mathrm{TNF}^{-1-}$ mice in CNS-TB, we also speculate the synergistic effect of myeloid and T cell-derived TNF in chronic infection. It has been demonstrated in a chimeric transfer study that both macrophage and T cell-derived TNF are required for sufficient and long-term protection against $M$. tuberculosis infection (26). The control of latent infection is TNF dependent that requires macrophage and $\mathrm{T}$ cells to form and maintain the granuloma structure $(32,42,43)$. Infected macrophages produce TNF and induce the expression of chemokines, such as IL-8, MCP-1, and RANTES, which provide signals for migration of immune cells to the sites of $M$. tuberculosis infection $(44,45)$. As evident in our study, we found deregulated expression of chemokines in the absence of TNF expression in myeloid and $\mathrm{T}$ cells that causes a profound effect on the cellular recruitment.

Tumor necrosis factor is involved in both immune and immunomodulatory responses and acts in synergy with T cell-derived IFN- $\gamma$ to enhance the macrophages antimycobactericidal activity of nitric oxide and other RNI by iNOS. IFN- $\gamma$ is mainly produced by $\mathrm{T}$ cells and natural killer cells in response to dying bacterialinfected macrophages $(46,47)$; the uncontrolled increase IFN- $\gamma$ concentrations observed in the respective mouse strains correlated with the increase infiltrating of effector CD4+ and CD8+ $\mathrm{T}$ cells. A study by Flynn et al. (1) using IFN- $\gamma^{-/-}$mice clearly demonstrated the important role of IFN- $\gamma$ in the protective immune response to $M$. tuberculosis infection, while other studies using transgenic mice have shown that IFN- $\gamma$ overexpression in the CNS increases disease progression $(48,49)$. Our studies that 
show a correlation between high IFN- $\gamma$ expression and advanced TB disease support these findings.

Besides increase production levels of IFN- $\gamma$, the cytokine IL-2 was found to be lower in $\mathrm{MT}^{-\mathrm{TNF}^{-/}}$and $\mathrm{TNF}^{-/-}$brains, yet, the infiltration of effector T cells was higher than in the TNF ${ }^{f / f}$ mice. This coincides with the previous findings of dysregulated $\mathrm{T}$ cell trafficking to the brains of IL-2-deficient mice attributes to CNS autoimmunity (50-52). Moreover, the loss of brain IL-2 expression changes the neuroimmunological milieu such as an increase in concentrations of endogenous CXCL10, MCP-1, and IL-15, which is a potent $T$ cell chemoattractant shares the same IL-2 receptor subunits for signal transduction (53-55). Originally, IL-2 described as a potent $\mathrm{T}$ cell growth factor is known to promote the proliferation and survival of effector $\mathrm{T}$ cells. Recent studies have highlighted the role of IL-2 in the regulation of immune responses and regulatory $\mathrm{T}$ cell (Treg) homeostasis where cytokine competition is crucial for the balance between tolerance and response (56-58). Tregs are a population of $\mathrm{T}$ cells characterized by the expression of CD25 (IL-2Ra) and the transcription factor Foxp3, and their general role has been demonstrated as immunosuppressive in various experimental settings of autoimmune diseases $(59,60)$. Another possibility of lower brain IL-2 production in $\mathrm{MT}^{-\mathrm{TNF}^{-/-}}$and $\mathrm{TNF}^{-/-}$mice may be a direct result of TNF deficiency. Although the proinflammatory effects of TNF signaling through TNFRp55 and TNFRp75 are well documented, increasing evidence indicates the immunoregulatory effects of TNF-TNFRs on Treg cell function $(59,61,62)$. The expansion of Tregs upon mycobacterial infection has been shown in animal and clinical studies $(63,64)$. Moreover, the accumulation of Tregs was found in the CNS after mycobacterial and viral infection, which regulates T cells trafficking to CNS $(18,65)$. We have previously shown a modulatory role of TNFRp75 shedding-mediated TNF signaling in IL-12-dependent dendritic cell migration and M. tuberculosis-specific T cell activation (33). Recently, it has been shown that TNF-TNFRp75 interaction plays a critical role in the

\section{REFERENCES}

1. Flynn JL, Goldstein MM, Chan J, Triebold KJ, Pfeffer K, Lowenstein CJ, et al. Tumor necrosis factor-alpha is required in the protective immune response against Mycobacterium tuberculosis in mice. Immunity (1995) 2:561-72. doi:10.1016/1074-7613(95)90001-2

2. Marino S, Sud D, Plessner H, Lin PL, Chan J, Flynn JL, et al. Differences in reactivation of tuberculosis induced from anti-TNF treatments are based on bioavailability in granulomatous tissue. PLoS Comput Biol (2007) 3:1909-24. doi:10.1371/journal.pcbi.0030194

3. Lin PL, Myers A, Smith L, Bigbee C, Bigbee M, Fuhrman C, et al. Tumor necrosis factor neutralization results in disseminated disease in acute and latent Mycobacterium tuberculosis infection with normal granuloma structure in a cynomolgus macaque model. Arthritis Rheum (2010) 62:340-50. doi:10.1002/art.27271

4. Allie N, Grivennikov SI, Keeton R, Hsu NJ, Bourigault ML, Court N, et al. Prominent role for $\mathrm{T}$ cell-derived tumour necrosis factor for sustained control of Mycobacterium tuberculosis infection. Sci Rep (2013) 3:1809. doi:10.1038/ srep01809

5. Tobin DM, Vary JC Jr, Ray JP, Walsh GS, Dunstan SJ, Bang ND, et al. The lta4h locus modulates susceptibility to mycobacterial infection in zebrafish and humans. Cell (2010) 140:717-30. doi:10.1016/j.cell.2010.02.013

6. Tobin DM, Roca FJ, Oh SF, Mcfarland R, Vickery TW, Ray JP, et al. Host genotype-specific therapies can optimize the inflammatory response to expansion of Tregs $(61,66,67)$. Here, we observed an increase in chemokine production in $\mathrm{MT}^{-\mathrm{TNF}^{-/}}$mice and comparable to $\mathrm{TNF}^{-/-}$mice, which correlated with increased recruitment of infiltrating leukocytes into the brain. Therefore, it is possible in our study that the absence of TNF disrupts Treg function and causes uncontrolled $\mathrm{T}$ cell responses during CNS-TB infection. Taken together, TNF production by myeloid cell and T-cell is pivotal in regulating $\mathrm{T}$ cell immunity.

In conclusion, our data demonstrate that ablation of TNF in myeloid and lymphoid $\mathrm{T}$ cells renders the protective immunity ineffective, leading to increase susceptibility. In conclusion, the findings in this study corroborate earlier reports of the importance of TNF in immune-mediated responses against tuberculosis. We further showed that the TNF production by both myeloid cell and T-cell is essential for this process and the future development of improved diagnostic and therapeutic strategies.

\section{AUTHOR CONTRIBUTIONS}

$\mathrm{N}-\mathrm{JH}, \mathrm{NMF}, \mathrm{RK}$, and NA were involved in experiments and data analysis. VQ and BR contributed to the experimental design. $\mathrm{N}-J \mathrm{H}$ wrote the manuscript. MJ oversaw the project. All authors read and approved the final manuscript.

\section{ACKNOWLEDGMENTS}

This study was supported by the National Research Foundation (South Africa), the South African Medical Research Council, University of Cape Town, and National Health Laboratory Service (South Africa). We thank Marilyn Tyler and Lizette Fick for their sterling contribution to the histology. A special thank you to Faried Abbass for technical support. We thank the staff of the Division of Immunology and the Animal Unit at the University of Cape Town for their contribution to animal care and technical support.

mycobacterial infections. Cell (2012) 148:434-46. doi:10.1016/j.cell.2011. 12.023

7. Be NA, Kim KS, Bishai WR, Jain SK. Pathogenesis of central nervous system tuberculosis. Curr Mol Med (2009) 9:94-9. doi:10.2174/156652409 787581655

8. Hernandez Pando R, Aguilar D, Cohen I, Guerrero M, Ribon W, Acosta P, et al. Specific bacterial genotypes of Mycobacterium tuberculosis cause extensive dissemination and brain infection in an experimental model. Tuberculosis (Edinb) (2010) 90:268-77. doi:10.1016/j.tube.2010.05.002

9. Tsenova L, Ellison E, Harbacheuski R, Moreira AL, Kurepina N, Reed MB, et al. Virulence of selected Mycobacterium tuberculosis clinical isolates in the rabbit model of meningitis is dependent on phenolic glycolipid produced by the bacilli. J Infect Dis (2005) 192:98-106. doi:10.1086/ 430614

10. Van Well GT, Wieland CW, Florquin S, Roord JJ, Van Der Poll T, Van Furth AM. A new murine model to study the pathogenesis of tuberculous meningitis. J Infect Dis (2007) 195:694-7. doi:10.1086/511273

11. Van Leeuwen LM, Van Der Kuip M, Youssef SA, De Bruin A, Bitter W, Van Furth AM, et al. Modeling tuberculous meningitis in zebrafish using Mycobacterium marinum. Dis Model Mech (2014) 7:1111-22. doi:10.1242/ dmm.015453

12. Mastroianni CM, Paoletti F, Lichtner M, D’Agostino C, Vullo V, Delia S Cerebrospinal fluid cytokines in patients with tuberculous meningitis. Clin Immunol Immunopathol (1997) 84:171-6. doi:10.1006/clin.1997.4367 
13. Misra UK, Kalita J, Srivastava R, Nair PP, Mishra MK, Basu A. A study of cytokines in tuberculous meningitis: clinical and MRI correlation. Neurosci Lett (2010) 483:6-10. doi:10.1016/j.neulet.2010.07.029

14. Olin MR, Armien AG, Cheeran MC, Rock RB, Molitor TW, Peterson PK. Role of nitric oxide in defense of the central nervous system against Mycobacterium tuberculosis. J Infect Dis (2008) 198:886-9. doi:10.1086/ 591097

15. Francisco NM, Hsu NJ, Keeton R, Randall P, Sebesho B, Allie N, et al. TNFdependent regulation and activation of innate immune cells are essential for host protection against cerebral tuberculosis. JNeuroinflammation (2015) 12:125. doi:10.1186/s12974-015-0345-1

16. Breder CD, Hazuka C, Ghayur T, Klug C, Huginin M, Yasuda K, et al. Regional induction of tumor necrosis factor alpha expression in the mouse brain after systemic lipopolysaccharide administration. Proc Natl Acad Sci U S A (1994) 91:11393-7. doi:10.1073/pnas.91.24.11393

17. Munoz-Fernandez MA, Fresno M. The role of tumour necrosis factor, interleukin 6, interferon-gamma and inducible nitric oxide synthase in the development and pathology of the nervous system. Prog Neurobiol (1998) 56:307-40. doi:10.1016/S0301-0082(98)00045-8

18. Lee J, Ling C, Kosmalski MM, Hulseberg P, Schreiber HA, Sandor M, et al. Intracerebral Mycobacterium bovis bacilli Calmette-Guerin infectioninduced immune responses in the CNS. J Neuroimmunol (2009) 213:112-22. doi:10.1016/j.jneuroim.2009.05.008

19. Kruglov AA, Lampropoulou V, Fillatreau S, Nedospasov SA. Pathogenic and protective functions of TNF in neuroinflammation are defined by its expression in T lymphocytes and myeloid cells. J Immunol (2011) 187:5660-70. doi:10.4049/jimmunol.1100663

20. Probert L. TNF and its receptors in the CNS: the essential, the desirable and the deleterious effects. Neuroscience (2015) 302:2-22. doi:10.1016/ j.neuroscience.2015.06.038

21. Tsenova L, Bergtold A, Freedman VH, Young RA, Kaplan G. Tumor necrosis factor alpha is a determinant of pathogenesis and disease progression in mycobacterial infection in the central nervous system. Proc Natl Acad Sci US A (1999) 96:5657-62. doi:10.1073/pnas.96.10.5657

22. Curto M, Reali C, Palmieri G, Scintu F, Schivo ML, Sogos V, et al. Inhibition of cytokines expression in human microglia infected by virulent and non-virulent mycobacteria. Neurochem Int (2004) 44:381-92. doi:10.1016/ j.neuint.2003.08.012

23. Rock RB, Hu S, Gekker G, Sheng WS, May B, Kapur V, et al. Mycobacterium tuberculosis-induced cytokine and chemokine expression by human microglia and astrocytes: effects of dexamethasone. J Infect Dis (2005) 192:2054-8. doi:10.1086/498165

24. Spanos JP, Hsu NJ, Jacobs M. Microglia are crucial regulators of neuro-immunity during central nervous system tuberculosis. Front Cell Neurosci (2015) 9:182. doi:10.3389/fncel.2015.00182

25. Barnes PF, Abrams JS, Lu S, Sieling PA, Rea TH, Modlin RL. Patterns of cytokine production by Mycobacterium-reactive human T-cell clones. Infect Immun (1993) 61:197-203.

26. Saunders BM, Briscoe H, Britton WJ. T cell-derived tumour necrosis factor is essential, but not sufficient, for protection against Mycobacterium tuberculosis infection. Clin Exp Immunol (2004) 137:279-87. doi:10.1111/ j.1365-2249.2004.02518.x

27. Harari A, Rozot V, Bellutti Enders F, Perreau M, Stalder JM, Nicod LP, et al. Dominant TNF-alpha+ Mycobacterium tuberculosis-specific CD4+ T cell responses discriminate between latent infection and active disease. Nat Med (2011) 17:372-6. doi:10.1038/nm.2299

28. Lee J, Reinke EK, Zozulya AL, Sandor M, Fabry Z. Mycobacterium bovis bacille Calmette-Guerin infection in the CNS suppresses experimental autoimmune encephalomyelitis and Th17 responses in an IFN-gamma-independent manner. J Immunol (2008) 181:6201-12. doi:10.4049/jimmunol.181.9.6201

29. Grivennikov SI, Tumanov AV, Liepinsh DJ, Kruglov AA, Marakusha BI, Shakhov AN, et al. Distinct and nonredundant in vivo functions of TNF produced by $\mathrm{t}$ cells and macrophages/neutrophils: protective and deleterious effects. Immunity (2005) 22:93-104. doi:10.1016/j.immuni.2004. 11.016

30. Segueni N, Benmerzoug S, Rose S, Gauthier A, Bourigault ML, Reverchon F, et al. Innate myeloid cell TNFR1 mediates first line defence against primary Mycobacterium tuberculosis infection. Sci Rep (2016) 6:22454. doi:10.1038/ srep 22454
31. Randall PJ, Hsu NJ, Quesniaux V, Ryffel B, Jacobs M. Mycobacterium tuberculosis infection of the "non-classical immune cell". Immunol Cell Biol (2015) 93:789-95. doi:10.1038/icb.2015.43

32. Ndlovu H, Marakalala MJ. Granulomas and inflammation: host-directed therapies for tuberculosis. Front Immunol (2016) 7:434. doi:10.3389/ fimmu.2016.00434

33. Keeton R, Allie N, Dambuza I, Abel B, Hsu NJ, Sebesho B, et al. Soluble TNFRp75 regulates host protective immunity against Mycobacterium tuberculosis. J Clin Invest (2014) 124:1537-51. doi:10.1172/JCI45005

34. Gomez Perdiguero E, Schulz C, Geissmann F. Development and homeostasis of "resident" myeloid cells: the case of the microglia. Glia (2013) 61:112-20. doi:10.1002/glia.22393

35. Prinz M, Priller J. Microglia and brain macrophages in the molecular age: from origin to neuropsychiatric disease. Nat Rev Neurosci (2014) 15:300-12. doi:10.1038/nrn3722

36. Ros-Bernal F, Hunot S, Herrero MT, Parnadeau S, Corvol JC, Lu L, et al. Microglial glucocorticoid receptors play a pivotal role in regulating dopaminergic neurodegeneration in parkinsonism. Proc Natl Acad Sci U S A (2011) 108:6632-7. doi:10.1073/pnas.1017820108

37. Goldmann T, Wieghofer P, Muller PF, Wolf Y, Varol D, Yona S, et al. A new type of microglia gene targeting shows TAK1 to be pivotal in CNS autoimmune inflammation. Nat Neurosci (2013) 16:1618-26. doi:10.1038/nn.3531

38. Kavanagh E, Burguillos MA, Carrillo-Jimenez A, Oliva-Martin MJ, Santiago $\mathrm{M}$, Rodhe J, et al. Deletion of caspase- 8 in mouse myeloid cells blocks microglia pro-inflammatory activation and confers protection in MPTP neurodegeneration model. Aging (Albany NY) (2015) 7:673-89. doi:10.18632/aging. 100805

39. Lieberman AP, Pitha PM, Shin HS, Shin ML. Production of tumor necrosis factor and other cytokines by astrocytes stimulated with lipopolysaccharide or a neurotropic virus. Proc Natl Acad Sci U S A (1989) 86:6348-52. doi:10.1073/ pnas.86.16.6348

40. Chung IY, Benveniste EN. Tumor necrosis factor-alpha production by astrocytes. Induction by lipopolysaccharide, IFN-gamma, and IL-1 beta. J Immunol (1990) 144:2999-3007.

41. Chung IY, Norris JG, Benveniste EN. Differential tumor necrosis factor alpha expression by astrocytes from experimental allergic encephalomyelitissusceptible and -resistant rat strains. J Exp Med (1991) 173:801-11.

42. Botha T, Ryffel B. Reactivation of latent tuberculosis infection in TNF-deficient mice. J Immunol (2003) 171:3110-8. doi:10.4049/jimmunol.171.6.3110

43. Jacobs M, Togbe D, Fremond C, Samarina A, Allie N, Botha T, et al. Tumor necrosis factor is critical to control tuberculosis infection. Microbes Infect (2007) 9:623-8. doi:10.1016/j.micinf.2007.02.002

44. Algood HM, Chan J, Flynn JL. Chemokines and tuberculosis. Cytokine Growth Factor Rev (2003) 14:467-77. doi:10.1016/S1359-6101(03)00054-6

45. Algood HM, Lin PL, Yankura D, Jones A, Chan J, Flynn JL. TNF influences chemokine expression of macrophages in vitro and that of CD11b + cells in vivo during Mycobacterium tuberculosis infection. JImmunol (2004) 172:6846-57. doi:10.3389/fmicb.2011.00002

46. Kubota K. A novel functional T cell hybridoma recognizes macrophage cell death induced by bacteria: a possible role for innate lymphocytes in bacterial infection. J Immunol (2006) 176:7576-88. doi:10.4049/jimmunol.176.12.7576

47. Kubota K. Innate IFN-gamma production by subsets of natural killer cells, natural killer $\mathrm{T}$ cells and gammadelta $\mathrm{T}$ cells in response to dying bacterial-infected macrophages. Scand JImmunol (2010) 71:199-209. doi:10.1111/j.1365-3083.2009.02366.x

48. Corbin JG, Kelly D, Rath EM, Baerwald KD, Suzuki K, Popko B. Targeted CNS expression of interferon-gamma in transgenic mice leads to hypomyelination, reactive gliosis, and abnormal cerebellar development. Mol Cell Neurosci (1996) 7:354-70.

49. Renno T, Taupin V, Bourbonniere L, Verge G, Tran E, De Simone R, et al. Interferon-gamma in progression to chronic demyelination and neurological deficit following acute EAE. Mol Cell Neurosci (1998) 12:376-89.

50. Huang Z, Dauer DJ, Ha GK, Lewis MH, Petitto JM. Interleukin-2 deficiency-induced $T$ cell autoimmunity in the mouse brain. Neurosci Lett (2009) 463:44-8. doi:10.1016/j.neulet.2009.07.013

51. Huang Z, Meola D, Petitto JM. Loss of CNS IL-2 gene expression modifies brain $\mathrm{T}$ lymphocyte trafficking: response of normal versus autoreactive Treg-deficient T cells. Neurosci Lett (2011) 499:213-8. doi:10.1016/j.neulet. 2011.05.230 
52. Petitto JM, Cushman JD, Huang Z. Effects of brain-derived IL-2 deficiency and the development of autoimmunity on spatial learning and fear conditioning. J Neurol Disord (2015) 3:196. doi:10.4172/2329-6895.1000196

53. Perera LP, Goldman CK, Waldmann TA. IL-15 induces the expression of chemokines and their receptors in T lymphocytes. JImmunol (1999) 162:2606-12.

54. Beck RD Jr, Wasserfall C, Ha GK, Cushman JD, Huang Z, Atkinson MA, et al. Changes in hippocampal IL-15, related cytokines, and neurogenesis in IL-2 deficient mice. Brain Res (2005) 1041:223-30. doi:10.1016/ j.brainres.2005.02.010

55. Huang Z, Ha GK, Petitto JM. IL-15 and IL-15R alpha gene deletion: effects on $\mathrm{T}$ lymphocyte trafficking and the microglial and neuronal responses to facial nerve axotomy. Neurosci Lett (2007) 417:160-4. doi:10.1016/ j.neulet.2007.01.086

56. Busse D, De La Rosa M, Hobiger K, Thurley K, Flossdorf M, Scheffold A, et al. Competing feedback loops shape IL-2 signaling between helper and regulatory T lymphocytes in cellular microenvironments. Proc Natl Acad Sci US A (2010) 107:3058-63. doi:10.1073/pnas.0812851107

57. Feinerman O, Jentsch G, Tkach KE, Coward JW, Hathorn MM, Sneddon MW, et al. Single-cell quantification of IL-2 response by effector and regulatory $\mathrm{T}$ cells reveals critical plasticity in immune response. Mol Syst Biol (2010) 6:437. doi: $10.1038 / \mathrm{msb} .2010 .90$

58. Hofer T, Krichevsky O, Altan-Bonnet G. Competition for IL-2 between regulatory and effector $\mathrm{T}$ cells to chisel immune responses. Front Immunol (2012) 3:268. doi:10.3389/fimmu.2012.00268

59. Ehrenstein MR, Evans JG, Singh A, Moore S, Warnes G, Isenberg DA, et al. Compromised function of regulatory $\mathrm{T}$ cells in rheumatoid arthritis and reversal by anti-TNFalpha therapy. J Exp Med (2004) 200:277-85. doi:10.1084/ jem. 20040165

60. Venken K, Hellings N, Liblau R, Stinissen P. Disturbed regulatory T cell homeostasis in multiple sclerosis. Trends Mol Med (2010) 16:58-68. doi:10.1016/j.molmed.2009.12.003

61. Chen X, Baumel M, Mannel DN, Howard OM, Oppenheim JJ. Interaction of TNF with TNF receptor type 2 promotes expansion and function of mouse CD4+CD25+ T regulatory cells. J Immunol (2007) 179:154-61. doi:10.4049/ jimmunol.179.1.154
62. Cargnelutti E, Arias JL, Valdez SR, Rabinovich GA, Di Genaro MS. TNFRp55 controls regulatory $\mathrm{T}$ cell responses in Yersinia-induced reactive arthritis. Immunol Cell Biol (2013) 91:159-66. doi:10.1038/icb. 2012.65

63. Chen X, Zhou B, Li M, Deng Q, Wu X, Le X, et al. CD4(+)CD25(+) FoxP3(+) regulatory $\mathrm{T}$ cells suppress Mycobacterium tuberculosis immunity in patients with active disease. Clin Immunol (2007) 123:50-9. doi:10.1016/ j.clim.2006.11.009

64. Scott-Browne JP, Shafiani S, Tucker-Heard G, Ishida-Tsubota K, Fontenot JD, Rudensky AY, et al. Expansion and function of Foxp3-expressing T regulatory cells during tuberculosis. J Exp Med (2007) 204:2159-69. doi:10.1084/ jem.20062105

65. Cervantes-Barragan L, Firner S, Bechmann I, Waisman A, Lahl K, Sparwasser $\mathrm{T}$, et al. Regulatory $\mathrm{T}$ cells selectively preserve immune privilege of self-antigens during viral central nervous system infection. J Immunol (2012) 188:3678-85 doi:10.4049/jimmunol.1102422

66. Kleijwegt FS, Laban S, Duinkerken G, Joosten AM, Zaldumbide A, Nikolic $\mathrm{T}$, et al. Critical role for TNF in the induction of human antigen-specific regulatory T cells by tolerogenic dendritic cells. J Immunol (2010) 185:1412-8. doi:10.4049/jimmunol.1000560

67. Chen X, Wu X, Zhou Q, Howard OM, Netea MG, Oppenheim JJ. TNFR2 is critical for the stabilization of the CD4+Foxp3+ regulatory T cell phenotype in the inflammatory environment. J Immunol (2013) 190:1076-84. doi:10.4049/ jimmunol.1202659

Conflict of Interest Statement: The authors declare that the research was conducted in the absence of any commercial or financial relationships that could be construed as a potential conflict of interest.

Copyright (c) 2017 Hsu, Francisco, Keeton, Allie, Quesniaux, Ryffel and Jacobs. This is an open-access article distributed under the terms of the Creative Commons Attribution License (CC BY). The use, distribution or reproduction in other forums is permitted, provided the original author(s) or licensor are credited and that the original publication in this journal is cited, in accordance with accepted academic practice. No use, distribution or reproduction is permitted which does not comply with these terms. 